\title{
Rhizomes and Roots of Rare Arctic-Alpine Snowfield Plants on the Edges of Retreating Snowfields at Glacier National Park, Montana
}

\author{
Apple, Martha E. ${ }^{1}$, M. K. Ricketts ${ }^{1}$, and L.G. Carlson ${ }^{1}$ \\ ${ }^{1}$ Department of Biological Sciences, Montana Tech of the University of Montana, Butte, Montana, USA, \\ 59701.
}

The glaciers and snowfields at Glacier National Park, Montana are disappearing due to climate change [1]. Snowfield plants rely on melting snow from the edges of snowfields and glaciers during the brief summer growing season in this otherwise harsh environment. Since the edges of snowfields and glaciers move as these icy bodies recede, snowfield plants live on changing edges and may lose this habitat altogether with the disappearance of snowfields and glaciers. Glacier National Park is home to rare arctic-alpine plants that inhabit the snowfield's edges and that live downstream and obtain their water, at least in part, from summer snowmelt. Thus, the habitats of these rare plants are endangered.

Plants are intrinsically linked to their environments, and plant functional traits are those characteristics of plants that influence their interactions with the environment [2]. Plant functional traits exist on the macroscopic, microscopic, physiological, biochemical, and temporal levels. For example, the presence of rhizomes is a plant functional trait. Rhizomes are macroscopic, underground horizontal stems that occur frequently in snowfield plants. Rhizomes provide a ready reservoir of carbohydrates that if mobilized and metabolized, can be used by snowfield plants for rapid growth; for withstanding adverse conditions before snowmelt; for production of adventitious roots; for clonal reproduction; and for production of buds. These buds can quickly sprout during snowmelt and grow into aerial shoots that may in turn produce flowers or spores. Rhizomes are also a key means of advance for pioneer species, which include plants colonizing a recently revealed snowfield's edge. Phenology is the science of the timing of biological events, and one consequence of climate change is that phenology can be offset. Therefore, rhizome physiology can be seen as a functional trait that is a coordinating mechanism for many phenological events in snowfield plants.

In 2012 and 2014, we established geospatially referenced transects perpendicular to the lateral and leading edges of snowfields at Mt. Clements, Siyeh Pass and Piegan Pass at Glacier National Park [3]. We collected leaves for morphometric measurements from $1 \mathrm{~m}^{2}$ quadrats placed at $5 \mathrm{~m}$ intervals along the $50 \mathrm{~m}$ transects. Functional traits of plants differed significantly with distance from the snowfields. Morphometric traits of leaves collected along an environment gradient extending from the edge of the vast Mt. Clements snowfield to the top of the steep $\left(35^{\circ}\right)$ Mt. Clements moraine were measured with Image-J and dry weights were obtained [4]. Specific leaf area, $\left(\mathrm{mm}^{-2} / \mathrm{mg}\right.$ dry weight, $)$ is an indirect measure of leaf density. Leaves with higher SLA generally have less densely packed cells. At the Mt. Clements moraine, community-weighted trait means of SLA decreased significantly with distance from the snow. Therefore, the leaves of the collective snowfield species were thinner, or less dense, near the snow where water availability was greater, and thicker, or with greater density, farther from the snow, where water availability decreased. Thinner leaves are less drought-tolerant than thicker, dense leaves with lower SLA. Leaf circularity was greater closer to the snow and leaf shape became more complex with increasing distance from the snow. Snowfield plants are likely to have herbaceous growth forms, have underground storage organs (including rhizomes, bulbs, corms, and taproots); and to have simple leaf shapes. Cushion plants and shrubs became more common with distance from the snow. Soil 
qualities as well as snow and water availability may influence the plants, as soils had a significantly greater proportion of fine particles at the edge of the Mt. Clements Moraine snowfield.

Plant functional traits also varied on the periglacial patterned ground at Siyeh Pass and Piegan Pass, which takes the form of a brown and green striped landscape of terraces with brown stony treads and green inclined risers. Nitrogen is relatively limited in alpine soils, and nitrogen-fixing members of the legume family (Fabaceae) grew on both the treads and the risers. On the risers, Salix arctica, the arctic willow, and Dryas octopetala, of the rose family (Rosaceae), are co-dominant low-growing ectomycorrhizal shrubs that form extensive mats $[5,6]$. Experimental warming of the rhizosphere fungi of $S$. arctica suggested that fungal community biomass increased with increased belowground allocation of carbon [7]. Alpine ectomycorrhizal symbioses and belowground carbon pools may therefore be influenced by the warmer temperatures associated with climate change. Seedlings and saplings of Pinus albicaulus (Whitebark Pine) and Abies lasiocarpa (Subalpine fir) associated with the risers but not with the treads. Plant communities differed markedly between the risers and the treads, which had a greater percentage of rare arctic-alpine plants. Plants on the stony treads had a greater incidence of aboveground, xeromorphic (drought tolerant) features. Alpine fell-field plants on calcareous soils of the northern Rocky Mountains of Montana and Wyoming had a high incidence of vesicular-arbuscular mycorrhizal colonization [8]. The specific mycorrhizal status of plants on the rocky treads of the periglacial patterned ground at Siyeh Pass and Piegan Pass remains to be investigated and would lend itself well to microscopy.

\section{References}

[1] Brown, J., J. Harper, and N. Humphrey. 2010. Cirque glacier sensitivity to 21st century warming: Sperry Glacier, Rocky Mountains, USA, Glob. Planet. Change. doi:10.1016/j.gloplacha.2010.09.001

[2] Venn, S., Pickering, C., and Green, K. 2014. Spatial and temporal functional changes in alpine summit vegetation are driven by increases in shrubs and graminoids. AoB PLANTS 6:plu008. Doi:10.1093/aobpla/plu008

[3] Apple, M. E. 2012. Measuring Impacts to Rare Peripheral Arctic-Alpine Plants at the Edges of Permanent Snowfields/Glaciers that are Receding due to Climate Change in Glacier National Park. RMCESU Report P12AC10557, MT-02.

[4] Schneider, C. A.; Rasband, W. S. \& Eliceiri, K. W. (2012), "NIH Image to ImageJ: 25 years of image analysis", Nature methods 9(7): 671-675, PMID 22930834

[5] Treu, R., Laursen, G.A., Stephenson, S.L., Landolt, J.C. and Densmore, R. 1995. Mycorrhizae from Denali National Park and Preserve, Alaska. Mycorrhiza 6(1):21:29.

[6] Bjorbaekmo, M.F.M., Carlsen, T., Brysting, A., Vralstad, T., Hoiland, K., Ugland, K.I., Gem, J., Schumacher, T., and Kauserud, H. 2010. High diversity of root associated fungi in both alpine and arctic Dryas octopetala. BMC Plant Biology, 10:244 doi:10.1186/1471-2229-10-224.

[7] Fujimura K.E., Egger K.N., Henry G.H , 2008 The effect of experimental warming on the rootassociated fungal community of Salix arctica. Isme Journal.2(1):105-114p.

[8] Lesica, P. and Antibus, R. K. 1986. Mycorrhizae of alpine fell-field communities on soils derived from crystalline and calcareous parent materials. Canadian Journal of Botany, 1986, 64(8): 1691-1697, $10.1139 / \mathrm{b} 86-226$

[9] The authors acknowledge funding from RM-CESU and acknowledge The Crown of the Continent Research Learning Center at Glacier National Park. 